\title{
ST BRUNO OF QUERFURT: THE MISSIONARY VOCATION
}

\author{
Darius Baronas
}

ABSTRACT The aim of this article is to reconstruct the picture of the missionary as it appears in the writings of St Bruno of Querfurt (d.1009). Scholars have noted for a long time that St Bruno saw a very close link between the missionary calling and martyrdom. From his writings it becomes quite clear that he personally had a desire to suffer martyrdom. Such a desire, however, did not have much in common with a precipitous drive to become a martyr. He saw it, rather, as a crown awaiting the missionary at the end of a long road of self-mortification and self-renunciation. He put forward for himself and for his ascetic readers a three-stage course of perfection: community life (coenobium) for beginners, a life in seclusion (eremus) for the advanced, and the mission to the pagans for the most perfect. Such a course of ascetic life was characteristic of Irish and Anglo-Saxon monks (in the sixth-eighth centuries) whose pilgrimages tended to evolve into missionary trips among the pagans. In the context of medieval missionaries St Bruno stood out as he personally pondered over this issue in a methodological fashion. In the eyes of the saint, preparation for missionary activities should lead to rational martyrdom (rationale martyrium) in which one could hardly fail to notice the original notion of martyrdom as a witness to the Faith. Another noteworthy feature of St Bruno's thoughts may be his insistence on having a papal licence to conduct evangelization, which was not asked for usually in his days. Thus, he may be viewed not only as a devotee of St Peter and his successors, but also as an advocate of papal missions, which tended to be most promising to newly converted rulers and their subjects.

Introduction St Bruno of Querfurt had a short but meaningful life. Living in this world, he managed to lay up treasures for himself in heaven, where neither moth nor rust corrupt, and where thieves do not break through or steal (Matt., vi. 20). His noble deed surpassed the limits of place and time and his example perhaps is no less significant and relevant today as it was more than several hundred years ago. First, it is important because the saint is 'inconvenient' for those modern Europeans who, ignoring the Christian roots of the continent, are turning it into the quagmire of barbarity and moral and intellectual darkness. St Bruno is significant because he is instrumental in 
discovering those virtues which are a sound basis for the solidarity of the European nations. In his own time he was not exceptional in that that led by the ideal of the love for his neighbour he set out to preach the gospel to the pagans in the most distant lands of Europe. He did that what hundreds of thousands of others had done before him, but he was the one who succeeded in approaching the ideal of the suffering Christ and in winning a martyr's crown. Following the example of his forerunners and friends, St Bruno sought to implement his Christian precept combining two principal elements - missionary activity and martyrdom. He distinguished himself as a prolific writer. His writings are characterized by emotional intensity and reflections of autobiographical nature, personal resolution and vigilance, and a strong sense of duty and penitence for his imperfection and sins. The personality and works of St Bruno have long since attracted the attention of researchers, and several monographs and a large number of articles by the scholars of various countries have been published. ${ }^{1}$ These numerous studies attest to the significance of St Bruno in the comprehension of the way of the nations of Central Europe towards modern times. They also show that the solution of concrete problems is slow and requires a lot of effort. Due to the scarcity of historical sources much of St Bruno's activities between Magdeburg and Rome and between Rome and Kiev will remain shrouded in mystery, despite scholarly endeavours to understand the saint, his time and milieu. In this article an attempt is made to reveal St Bruno's conception of the missionary's vocation on the basis of his own writings.

The majority of the studies, published up to now, have been focused either on the reconstruction of St Bruno's life or on the analysis of his political views or on the state of Christianity in different countries of Central Europe in the late tenth and early eleventh centuries. Meanwhile few are the works investigating St Bruno's missionary vocation as if from within concentrating on his profile reflected in his own writings.

${ }^{1}$ H.G. Voigt, Bruno von Querfurt. Mönch, Eremit, Erzbischof der Heiden und Märtyrer (Stuttgart, 1907); R. Wenskus, Studien zur historisch-politischen Gedankenwelt Bruns von Querfurt (= Mitteldeutsche Forschungen, 5) (Münster, Köln, 1956). For an extensive bibliography, see 1009 metai: šv. Brunono Kverfurtiečio misija, comp. I. Leonavičiūte (Vilnius, 2006). More recent research is presented in: Święty Brunon. Patron lokalny czy symbol jedności Europy i powszechności Kościoła, ed. Andrzej Kopiczko (Olsztyn, 2009). 
St Bruno's Life The future saint was born to Count Bruno of Querfurt and his wife Ida around 974. He was sent to the Magdeburg cathedral school where he received excellent education seen in his later Latin texts based on the wisdom of the Scriptures and the maxims of ancient Rome. The young Bruno was also distinguished for his musical endowments. ${ }^{2}$ After graduation he became a canon of St Maurice's church in Magdeburg. Properly exploited great gifts and noble birth - the counts of Querfurt were related even to the imperial Ottonian/Liudolfing dynasty - enabled him in the third decade of his life (in the second half of 997) to become court chaplain to the young emperor Otto III (983-1002). ${ }^{3}$ Excellent promotion prospects opened for the young clergyman. However, his further life took an unexpected turn of events: early in 998 he and Otto III went to Rome and already in February Bruno entered the monastery of Ss Alexius and Boniface. It could be surmised that such a step was taken by him in the aftermath of the martyrdom of St Adalbert-Wojciech in Prussia in 997; it was an event, which produced a profound effect on the contemporary secular and clerical elite of Western Europe. ${ }^{4}$ It should be noted that the process of Christianization in Europe in the early Middle Ages until the times of Charlemagne proceeded very peacefully - cases of martyrdom were comparatively rare since the time when the persecution of the Church ceased. ${ }^{5}$ White martyrdom rather than red one, a patient struggle with one's own sins and those of others rather than a prospect of a quick violent death bearing witness to the truth of the faith were the everydayness of the ascetics committed to Christ. Meanwhile St Adalbert's martyrdom indicated that divine grace could be won by evangelizing in the vicinity of the new Christian countries of Europe.

2 Petri Damiani, Vita Beati Romualdi, a cura di G. Tabacco (=Fonti per la Storia d'Italia, t. 94), (Rome, 1957), p. 56: 'Erat autem adprime liberalium artium doctrinis instructus maximeque in modulationis musicę studiis approbatus'; Wenskus, Studien, p. 79.

${ }^{3}$ K. Görich, Otto III.: Romanus, Saxonicus et Italicus. Kaiserliche Rompolitik und sächsische Historiographie (Sigmaringen, 1993), p. 18.

${ }^{4}$ In greater detail, see G. Labuda, Święty Wojciech, Biskup-Męczennik, Patron Polski, Czech i Więger (Wrocław, 2000), pp. 258-262; T. Dunin-Wąsowicz, 'Ślady kultu świętego Wojciecha w Europie zachodniej około 1000 roku', Tropami Świętego Wojciecha, ed. Z. Kurnatowskia (Poznań, 1999), pp. 221-234.

${ }^{5}$ R. Fletcher, The Conversion of Europe: from Paganism to Christianity, 371-1386 AD (London, 1998), p. 232.

6 'Brunonis Vita Quinque Fratrum', Monumenta Poloniae Historica [henceforth $-M P H]$ (Cracow, 1893), t. 6, p. 398. 
That event shocked him deeply. Therefore St Adalbert seemed to him rara avis. ${ }^{6}$ The descriptions of the martyrdom of St Adalbert showed that he was killed by the pagans practicing demonic cults; they wore ritual dog-masks - thus the plausibility of the stories about dog-headed people (cynocephali), known to the majority of the contemporary Christians only from hearsay evidence or vague reports, was confirmed. ${ }^{7}$ Martyred on 23 April 997, the feast of St George the Martyr, St Adalbert faithfully followed the passion of Christ and in his turn was a perfect example to St Bruno.

Bruno's readiness for martyrdom is clearly attested by the choice of his monastic name of Boniface. Opinions vary as to the name of which Boniface the future saint took - the martyred Boniface of the time of the emperor Decius (d. ca. 304) or the Anglo-Saxon missionary archbishop, Boniface (perished in 754). Damian writes that seeing the church of the martyr of old times Boniface Bruno exclaimed: 'I am also Boniface. Therefore why cannot I too be a martyr for Christ?'. ${ }^{8}$ This episode suggests that Bruno already had the name of Boniface and that he should be associated with the apostle of Germany St Boniface and that he had desired to die a martyr's death at least from 998; his wish came true eleven years later. The idea of preaching the gospel and the desire for martyrdom had became Bruno's objectives and he had started preparing to fulfil these tasks. And it was not an accidental excitement but a thorough purposeful preparation.

Bruno's thoughts about spreading Christianity and his missionary journeys are found in his three main works - The Life of St Adalbert, The Five Martyred Brothers and A Letter to the German King Henry II (1002-1024). ${ }^{9}$ They were written at the peak of his missionary activity. The letter to Henry II was written just before his last mission, and consequently could be treated as a kind of the saint's will. His works differed from those of his contemporaries in that they abounded in autobiographical facts, which showed his

${ }^{7}$ Cf. I. Wood, The Missionary Life: Saints and the Evangelisation of Europe, 400-1050 (Harlow, 2001), pp. 250-253.

${ }^{8}$ Damiani, Vita, p. 56: Hic itaque cum in capella regia moraretur, videns ecclesiam antiqui martiris Bonifatii, mox exemplo sui equivoci ad martirii desiderium provocatus, ait: "Et ego Bonifatius vocor. Cur ergo etiam ipse Christi martir esse non debeo»? This church belongs to the aforementioned monastery of Ss Alexius and Boniface.

9 '[Brunonis] Passio Sancti Adalberti episcopi et martyris', MPH, t. 1, pp. 189-222; 'Brunonis Vita', pp. 388-428; 'Epistola Brunonis ad Henricum II', ibid., t. 1, pp. 224-228. 
attitude to the people he dealt with and the values he held. In order to understand all that it is necessary to take into account both these texts and their contexts.

Hard Times Bruno lived in bad unhappy times, which became troubled at the end of the rule of Otto I (936-973). His son Otto II acting on naïve advice began ruling unwisely and ruined the order of his father's stable rule. Germany suffered defeat. 'Otto, the pious stern ruler, departed this life; he knew how to curb disorder and his golden age is remembered [by the German land] with great lament now when Holy Church is restrained in various ways without cease by rising enemies', ${ }^{10}$ wrote Bruno. The Slavic tribes inhabiting the area between the Elbe and the Oder were among the most implacable enemies. In 983 they rose against German rule, reverted to paganism and set up a theocratically organized aggressive union of the Liutizi and other tribes. The forces of the emperor Otto III and his allies the Polish rulers Mieszko (ca. 960-992) and Bolesław the Brave (992-1025) could not suppress this hotbed of renewed paganism. Things got even worse when, after the sudden death of Otto III early in 1002, discord erupted between Bolesław the Brave and Henry II; the latter concluded an agreement with the Liutizi which was directed against the Poles. In Bruno's opinion this agreement was a stinging slap in the face and a great scandal; and he expressed his indignation in the words of St Paul: 'And what concord hath Christ with Belial?', ${ }^{11}$ how can light be compared to darkness? What is there in common between Zuarasi(ci) the devil and the leader of the saints, your and our Maurice? How can the holy spears be lined up with the standards of the devils, fed with human blood? ${ }^{12}$ Such and the like words were directed to King Henry II whom Bruno urged to be a merciful ruler and stop fighting against Bolesław the Brave. 'Is it not better to fight against the pagans for the sake of Christianity', he wrote, 'than to use force for the sake of mundane honour?'13 Bruno regretted that Henry II did not contemplate noble struggles against the heathen Liutizi and thus deserve the name of apostle in the eyes of God. ${ }^{14}$ The saint exclaimed, 'Alas, unhappy

10 '[Brunonis] Passio Sancti Adalberti', pp. 195-196. More on political views of Bruno of Querfurt, see Görich, Otto III, pp. 17-51.

${ }^{11}$ Second Epistle to Corinthians, vi, 15.

12 Epistola Brunonis ad Henricum II, p. 226.

${ }^{13}$ Ibid., pp. 226-227.

${ }^{14}$ Ibid., p. 227. 
times! After the holy emperor Constantine the Great, and after the most excellent Charles turned the example of the devout ruler, there are some who persecute a Christian but hardly anybody who would convert a pagan!'. ${ }^{15}$

Bruno had already used nearly the same phrases in his St Adalbert's Life. ${ }^{16}$ That shows that he was in fact concerned with how the Christian rulers were ready to serve the Christian Church, to support the missionaries and in the case of necessity to organize military expeditions against the pagans. ${ }^{17}$ It must be accentuated that in urging Christian rulers to take active measures against the pagans Bruno relied on $\mathrm{St}$ Luke's Gospel. That particular passage deals with a hospitable host and ungrateful guests, who being invited to a great banquet began making excuses. The host became angry and told the servant to bring in the poor, the crippled, the blind and the lame and finally 'compel the people to come in' from the highways and hedges 'that my house may be filled' (Luke xiv:16-24). The phrase compellere intrare 'to compel to come in' was used by St Bruno more than once, but that does not indicate that he was a thoughtless protagonist of coercion with respect to the pagans. In-depth research reveals that St Bruno approved the use of coercion only in special cases relating to pagan apostates. In the opinion of contemporary Christians, having rejected Christianity, apostates did not become innocent pagans again - they were subject to the same laws and customs as heretics and schismatics. ${ }^{18}$ The Liutizi were just such apostates.

St Bruno approved the support of secular rulers to the missionaries in the cases when the elite of local pagans prevented a free preaching of the gospel. The saint deliberated and sought political solutions for dealing with pagan apostates and outrageously obstinate pagans. These deliberations, however, did not deal with the essence of the missionary's vocation. In fact, St Bruno was an adherent of the peaceful spreading of the gospel as was attested both by his works and his martyr's death. He did not consent to inadequate and unlawful draconian measures. In his opinion, the good news

${ }^{15}$ Damiani, Vita, p. 57.

16 '[Brunonis] Passio Sancti Adalberti', p. 195.

${ }^{17}$ A. Kuźmiuk-Ciekanowska, 'Piśmiennictwo świętego Brunona z Kwerfurtu', Święty Brunon, ed. Andrzej Kopiczko, pp. 308, 314.

${ }^{18}$ Cf. H.-D. Kahl, 'Compellere intrare. Die Wendenpolitik Bruns von Querfurt im Lichte hochmittelalterlichen Missions- und Völkerrechts', Heidenmission und Kreuzzugsgedanke in der Deutschen Ostpolitik des Mittelalters, ed. H. Beumann (Darmstadt, 1963), pp. 199-220. 
of salvation in Jesus Christ had to be preached only in peaceful ways to those who had not yet heard the missionary word. All in all, such is the portrait of Bruno as a missionary.

Preparation for the Mission According to Bruno only well prepared ascetics were suited for missionary work. The preparation had to begin with personal perfection - the struggle with one's sins, vices, and imperfections. After becoming a monk Bruno began practising strict ascetics - he went on fasts for long periods and ate only on Thursdays and Sundays and used to lie naked in a thicket of stinging nettles or thorns. When, on seeing this, one of St Romuald's brethren rebuked him for hypocrisy and vanity, Bruno answered: 'You take care of the faithful; I am concerned with the martyrs'. ${ }^{19}$ The most appropriate place for such conflicts was the monastery. In Bruno's words, people seeking the ways of the Lord could find threefold virtues in the monastery: the beginners a communitarian life, the advanced, seeking the living God, a life in seclusion, and the most perfect, wishing to separate from their body and be with Christ, preaching the gospel to the pagans. ${ }^{20}$ In this characteristic of the monastic way of life Bruno expressed one of the most significant ideals of the Camaldolese order. ${ }^{21}$ It was namely a monastery of this type that the emperor Otto III and the Polish ruler Bolesław the Brave wanted to establish in the eastern periphery of Christian lands in Poland. ${ }^{22}$ St Bruno supported enthusiastically such evangelical efforts.

The stages of the monastic life lead from a communal monastic life to the hermit community and further to preaching the gospel to the pagans. ${ }^{23}$ First one retreated from the secular world to the

${ }^{19}$ Damiani, Vita, p. 57.

20 'Brunonis Vita Quinque Fratrum', pp. 392-393: [...] tripla commoda querentibus viam Domini, hoc est noviter venientibus de seculo desiderabile cenobium, maturis vero et Deum vivum sicientibus aurea solitudo, cupientibus dissolvi et esse cum Christo euangelium paganorum. The same idea is repeated by Bruno once more by characterizing the deepest wishes of Otto III which were fated not to materialize. Cf. ibid., pp. 400-401: Et divina clemencia suam infirmitatem confortante, meliora volebat, qui etiam tria maxima bona, quorum unum ad salutem sufficit, monachicum habitum, heremum et martyrium toto desiderio ardebat.

${ }^{21}$ J. Sydow, 'Probleme der camaldulensischen Ostmission', Heidenmission und Kreuzzugsgedanke, pp. 148-149.

22 J. Strzelczyk, Otton III (Wrocław, 2000), pp. 181-183; R. Michałowski, Zjazd Gnieźnieński: religijne przesłanki powstania arcybiskupstwa gnieźnieńskiego (Wrocław, 2005), pp. 226-227, 341.

${ }^{23}$ Cf. also A. Kuźmiuk-Ciekanowska, 'Piśmiennictwo', p. 310. 
monastery and from there to a more secluded environment. Such persons separated themselves from their relatives and other people and for the greater love of God were ready to preach gospel to the pagans. This type of monastic life was special to the sixth-eighthcentury movement of Irish and Anglo-Saxon monks who started founding monasteries on the Continent. Many an Irish monk took the Lord's call to Abraham: 'The Lord had said to Abram: "Leave your country, your people and your father's household and go to the land I will show you" (Gen. xii:1). The same argument is found in The Five Martyred Brothers by Bruno, in which Benedict was referred to as a hermit leaving his native land. ${ }^{24}$ This tradition of the Irish monks of the early Middle Ages contributed to the development of pilgrimage into missionary activities. ${ }^{25}$ This tendency became a consciously desired aim for Bruno and his companions. Pilgrimage developing into mission and ending in martyrdom is vividly described in St Adalbert's Life by Bruno. Adalbert's pilgrimage to the holy places of France such as Tours with a basilica raised above St Martin's tomb, Paris with the last resting place of St Dionysius the Aeropagite and the monastery of Fleury with St Benedict's relics in its basilica was followed by the monk's glorious martyrdom mission to Prussian lands. ${ }^{26}$

Bruno's monastic life comprised the following phases: monastery, life in seclusion (eremitism), mission, and martyrdom. Having spent some time in the monastery of Ss Alexius and Boniface, Bruno joined St Romuald and his hermits in the autumn of 1000. Due to frequent visitors and the contemporary unstable situation in Rome, the hermits moved to Pereum near Ravenna and settled there in a secluded marshy locality in the upper reaches of the river Po. Living there Bruno made friends with Benedict, St Romuald's possibly most beloved disciple. Otto III's request to send missionaries to Polish lands and talks with Bruno inspired Benedict to spread the gospel. These were the arguments urging Benedict to engage in missionary work: 'What is the use of us living in this unhealthy swampy place where nearly all of us are ill? What manual jobs can we do in our cells if on Sunday we cannot walk on our feet to the church to receive Holy Communion? Will reading be of any benefit and will prayer be fervent if we cannot get out of bed with our rheumatic joints? ... Would it not be better if we, instead of vainly waiting

\footnotetext{
24 'Brunonis Vita Quinque Fratrum', p. 389.

${ }^{25}$ Fletcher, The Conversion, p. 94.

26 '[Brunonis] Passio Sancti Adalberti', pp. 206-207.
} 
for death in this bog, could get there where we could do these two things?' 27 And the two things were the Benedictine ora et labora. This Benedictine ideal penetrates the entire Life of St Adalbert.

Perceiving that the pagans reacted to the missionaries' words by gnashing teeth, foaming at the mouth and threatening to kill, St Adalbert started seeking some new ways to make the saving of souls more successful. He asked his companions whether it would not be better to put on clothes similar to those worn by the pagans, to grow long hair and beards and to look more like them. Or perhaps to settle among them and to earn subsistence by their own manual labour thus creating more favourable conditions for evangelizing. ${ }^{28}$

It is difficult to say definitely whether these ideas recorded by Bruno belonged to Adalbert or Bruno himself. On balance, it is beside the point. The pagans were also similarly referred to in The Five Martyred Brothers. ${ }^{29}$ Consequently, it could be considered that such were the thoughts of the missionaries after their contacts with the pagans. Such authentic attestations are rare in contemporary sources - therefore Bruno's writings occupy a special place in the research of the history of medieval missions.

Bruno wrote St Adalbert's Life at a time when he suffered a severe blow of fate. A community of four hermits, settled in Poland, did not await Bruno who was late. On an autumn night in 1003, during St Martin's vigil (10-11 November) the community was massacred by local robbers expecting in vain to find gold and silver there. Bruno reproached himself for this disaster and if performing penance wrote The Five Martyred Brothers. The death of Benedict and John, accepted willingly with forgiveness for their foes, soon made them martyrs. Determined to convert the pagans and being ready for martyrdom they almost immediately won a martyr crown. This kind of death was regarded by Bruno as a particular divine grace. According to the saint, not only death but also any blow suffered for the sake of Christ should be treated as the Lord's favour. When Adalbert experienced a blow with an oar on his back, Bruno rhetorically asked whether there was anything in this world equal to the voluntary suffering for Christ: 'After all, even a pearl does not sparkle so brightly in a heap of dirt, or the royal purple among common men, or even the rose on the ground; neither does the sun

\footnotetext{
27 'Brunonis Vita Quinque Fratrum', p. 394.

28 '[Brunonis] Passio Sancti Adalberti', p. 214.

${ }^{29}$ Wood, The Missionary Life, p. 239.
} 
shine so brightly in the sky as a blow in a tender heart so joyously accepted for Christ's glory!' 30

Bruno's writings show that mission and martyrdom were closely connected. Nevertheless, readiness for martyrdom on the part of Bruno and his companions should not be identified with self-admiration or impulsiveness. On the contrary, repenting for his sins Bruno indicated that personal whims prevented the accomplishment of the mission and finally martyrdom. Only the abdication of his will enables a man to rely on the Lord's mercy and makes it possible for a weak man to endure a martyr's death. According to Bruno, blood, shed for Christ, wipes away the sins totally and completely, while the water of baptism only washes them. Thus, the martyr earns the grace of meeting the Lord directly and achieving personal salvation.

However, that was not the only concern of a true missionary and martyr. There was one more, perhaps not less important, aspect, and that was winning for Christ as many souls as possible. This, so to say, quantitative aspect was very important for Bruno and his companions. For the sake of soul salvation they learnt a Slavic language, grew long hair, and wore secular clothes in order to open more efficiently the way to eternal life for the pagans. ${ }^{31}$ A deep desire for the martyr's crown had to be combined with prudent behaviour. According to both the five martyred brothers and to Bruno, such preparation had to give a chance for 'rational martyrdom' (rationale martyrium) in which the meaning of primary martyrdom as a testimony of faith was evident. ${ }^{32}$

St Adalbert's evangelical activity was short-lived, the five martyred brothers did not go on a mission at all, meanwhile St Bruno remained for quite a long time in the missionary field. In 1004, ordained as a missionary bishop by archbishop Tagino of Magdeburg, he went to the eastern area of Hungary where he preached Christianity to the Szeklers. He then journeyed to the steppes of the Pechenegs, Poland and the Prussian lands, where finally at the border between Rus' and Lithuania he won the martyr's crown - 'quiet as a lamb'. ${ }^{33}$ In the

30 '[Brunonis] Passio Sancti Adalberti', p. 213.

31 'Brunonis Vita Quinque Fratrum', p. 426: Volebant suscitare ad vitam christianitatis mortuos paganos, putantes tanto plus misericordiae invenire in conspectu imperatoris, quantum in eius servicium, pro quarum amore non pepercit unigenito Filio, plus inventarum animarum advexissent.

32 Ibid., p. 409.

33 'Thietmari Merseburgensis episcopi Chronicon', Monumenta Germaniae Historica. Scriptores rerum Germanicarum. Nova Series, t. 9 (Berlin), 1935, p. 388. 
last years Bruno extended his missionary activities from the Baltic to the Black Sea, and he reached the most far-off lands known to European Catholics. Thus, he did his duty towards the Church.

Bruno and his companions particularly valued the pope's authorization to spread the gospel among the pagans. At that time such permission was not mandatory. ${ }^{34}$ Nevertheless, Bruno again revealed himself in contemporary society as a high-ranking person who in deference to the papal institution sought to make his contribution to the renewal of the world and to make it better and more beautiful. ${ }^{35}$ Bruno's exceptional accentuation of the rights of the Holy See was closely associated with his active participation in papal missions. The missions sanctioned by the pope or based on his authority offered most promising prospects for the rulers and their subjects since they did not raise the question of political domination in the neophyte countries. ${ }^{36}$

St Bruno's missionary activities showed that the Gospel could receive favourable response even from the most atrocious pagans. After his arrival in 1008 at the Pechenegs, in his words 'the most cruel of all pagans' (omnium paganorum crudelissimos), Bruno managed to baptize at least thirty of them and to see about the truce between them and Grand Duke Vladimir of Kievan Rus. ${ }^{37}$ Even the same Prussians, not long ago having killed St AdalbertWojciech, this time, in Damian's words, 'showed cruel mercy'38 and allowed him to go as far as the border between Lithuania and Rus' during his last mission. In this region the initial successful apostolic activity finally ended in a tragic death for St Bruno. And that was unambiguous evidence that where a missionary could expect to gather a plenteous harvest of souls, he could have to pay the dearest price - his life - for it there.

${ }^{34}$ D. Sikorski, 'Model misji za czasów św. Brunona', Święty Brunon, ed. Kopiczko, pp. 61-62.

${ }^{35}$ On the contemporary situation of the papal institution, see Historia chrześcijaństwa: Religia-kultura-polityka, t. 4: Biskupi, mnisi i cesarze 610-1054 (Warszawa, 1999), pp. 624-633.

${ }^{36}$ D. Baronas, 'Paskutinè šv. Brunono Kverfurtiečio misija geopolitikos kontekste', Lietuvos istorijos metraštis, 2001/2 (Vilnius, 2002), p. 25. About the peculiarities of the missions sanctioned or supported by the emperors, kings and popes, see A. Angenendt, Kaiserherrschaft und Königstaufe. Kaiser, Könige und Päpste als geistliche Patrone in der abendländischen Missionsgeschichte (=Arbeiten zur Frühmittelalterforschung, Bd. 15) (Berlin, New York, 1984).

37 'Epistola Brunonis ad Henricum II', p. 224.

${ }^{38}$ Damiani, Vita, p. 58. 
Viewed from the perspective of a thousand years this victim can be valued not only in terms of eternal salvation but also from a purely secular viewpoint - Lithuania, mentioned for the first time in connection with St Bruno's martyrdom, is alive today and can enjoy the fruits of the faith brought by one of the most eminent medieval European missionaries.

Translated by Alfoncas Laučka

\section{Author Details}

Dr Darius Baronas works at the Department of Palaeography of the Lithuanian Institute of History. His fields of research are history of the Middle Ages, Christianization of Lithuania in the fifteenth to eighteenth centuries, and the history of the Friars Minor in Lithuania.

Address: Lithuanian Institute of History, Kražių 5, LT-01108 Vilnius

Email: baronas@istorija.lt

\section{ŠV. BRUNONAS KVERFURTIETIS: MISIONIERIAUS PAŠAUKIMAS}

Santrauka

\section{DARIUS BARONAS}

Šiame straipsnyje stengiamasi atskleisti šv. Brunono Kverfurtiečio misionieriaus profili, ryškejjanti iš jo rašytinio palikimo. Dalyko literatūroje jau seniai pažymèta, kad pagrindiniuose šv. Brunono kūriniuose, tokiuose kaip Šv. Adalberto gyvenimas, Penkių broliu kankinių gyvenimas ir Laiškas vokiečiu karaliui Henrikui II, gana ryškūs autobiografiniai motyvai. Tokia šių kūrinių ypatybe leidžia geriau pažinti ir pačią šv. Brunono asmenybę, ir tą idealą, i kuri jis orientavosi. Šv. Brunonui būdingas misionieriaus gyvenimo kelias turejo vesti per tris pakopas: per bendruomeninį vienuolyna, skirtą pradedantiesiems, per erema, skirtą toliau pažengusiems, ir per pagonių evangelizavimą iki pat kankinystès. Toks kelias rodo, kad galutinis misionieriaus tikslas - Evangelijos skelbimas pagonims - turèdavo realizuotis tik tada, kai misionierius jau buvo gana toli pažengęs asmeninio tobulejjimo kelyje ir išsižadėjęs paskutinių savo valios, kurią šv. Brunonas prilygino savivalei, likučių. Šv. Brunono raštuose su dideliu patosu aprašomas nuolankus pasiryžimas priimti kančią dèl Kristaus. Šios intymiausios ištarmès rodo, kad šv. Brunonas savo esme buvo taikaus Evangelijos skelbimo šalininkas. Tačiau tai dar ne iki galo atskleidžia šv. Brunono požiūrị i pagonių evangelizavimą apsikritai. Mąstydamas apie krikščionių valdovų priedermes, jis pritarè minčiai, kad jie turị teisę ir pareigą prireikus pavartoti prievartą prieš pagonis, bet tik prieš tuos, kurie atsimetę nuo Bažnyčios arba piktybiškai trukde laisvam Evangelijos skelbimui. O Evangelijos dar nepažinusiems ar jos negirdejjusiems pagonims, anot šv. Brunono, tinkamas tik taikus tikejimo skelbimas. Kitas svarbus šv. Brunono raštų bruožas yra tai, kad juose stipriai pabrèžiamos Apaštalų Sosto prerogatyvos sprendžiant misijų reikalus, tad šv. Brunoną galima laikyti popiežiškuju misijų šalininku. Tokio pobūdžio misijos buvo palankiausios naujakrikštams, nes jos nekeldavo politinio dominavimo klausimo. Dẻl gausių minčių apie misijas šv. Brunono raštuose jie yra ypatingos svarbos šaltinis tiriant Viduramžių misijų istoriją. 